International Journal of Public Finance
RESEARCH
ERTICLE

\title{
Fiscal Decentralization in Turkey and Differentiation in Selected Provinces
}

\begin{tabular}{|c|c|}
\hline & $\begin{array}{c}\text { Ahmet Güzel }{ }^{1} \\
\text { Hakkı Hakan Yılmaz }^{2}\end{array}$ \\
\hline ARTICLE INFO & \multirow{4}{*}{$\begin{array}{l}\text { A B S T R A C T } \\
\text { In this study, fiscal decentralization in Turkey was first considered in terms } \\
\text { of the size of local governments within the general government at the } \\
\text { macro level, and then the differentiation of fiscal decentralization among } \\
\text { the local governments on the basis of selected provinces was examined. } \\
\text { The revenue and expenditures of local governments in Turkey have } \\
\text { increased as a proportion of GDP, while the level of fiscal decentralization } \\
\text { has shown a distinctive structure especially since } 2000 \text { s. Results indicate } \\
\text { that there is no efficient calculation methodology for achieving vertical } \\
\text { equality. The objective for achieving horizontal equalization in the transfer } \\
\text { system remains also limited. Fiscal decentralization rates differ between } \\
\text { provinces. Intergovernmental revenue sharing system and differentiation } \\
\text { in own source revenues mainly resulting from the income levels of the } \\
\text { regions clearly shows that there has been an inadequate vertical and } \\
\text { horizontal imbalances and current sharing system somehow increases } \\
\text { inequalities among provinces. }\end{array}$} \\
\hline $\begin{array}{l}\text { Submitted : } 18.10 .2017 \\
\text { Revised : 22.03.2018 } \\
\text { Accepted : } 24.04 .2018 \\
\text { Available : } 30.07 .2018\end{array}$ & \\
\hline $\begin{array}{l}\text { JEL classification: } \\
\mathrm{H} 71, \mathrm{H} 72\end{array}$ & \\
\hline $\begin{array}{l}\text { Keywords: } \\
\text { Local Authorities, Fiscal } \\
\text { Decentralization, } \\
\text { Revenue Sharing }\end{array}$ & \\
\hline
\end{tabular}

\section{Introduction}

Decentralization means delegation of responsibilities from central authority to quasi-independent government organizations, private sector or sub-administrative units. In other words decentralization; refers to the transfer of administrative political or financial responsibilities to sub-management levels (Rondinelli, 1999: 2). Decentralization, also seen as a means of increasing efficiency and accountability, is

1 PhD student and TCA senior auditor, (https://orcid.org/0000-0001-7314-4484), Turkish Court of Accounts, Ankara University Faculty of Political and Administrative Science, Department of Public Finance, aguzel80@gmail.com

2 Prof. Dr., (https://orcid.org/0000-0003-3046-3236), Ankara University Faculty of Political and Administrative Science, Department of Public Finance, hakkihakanyilmaz@yahoo.com (Corresponding Author). 
also defined as the transfer of political, financial and managerial power to decentralized units (Burki et al, 1999: 2-3).

Fiscal decentralization is to be transferred to financial resources to local management to meet the responsibility of local tasks (Yılmaz et al, 2017b). In other words, fiscal decentralization to meet the duties and responsibilities transferred to local management is shared with the local management of financial resources. Fiscal decentralization has three important components: (i) revenue assignments and expenditure responsibilities, (ii) grants, and (iii) subnational borrowing (Ussi, 2007: 8).

In this study, fiscal decentralization in Turkey will first be addressed in terms of the size of local governments at macro level regarding both expenditure and revenues. Later on, the differentiation of fiscal decentralization among local governments on the basis of selected provinces will be analyzed.

The implementation of the conventional measures of the degree of fiscal decentralization, expenditure share and revenue share (Oates, 1972) in certain provinces of Turkey, is the basis of this paper. The findings of the study reveal that the level of financial decentralization in Turkey differs between the provinces within the framework of the public fiscal policies and the ruling government decisions.

The study consists of four main parts. In the second part, local governments are mentioned in Turkey and the structure of the general government is explained. In the third chapter, the method of measuring the financial decentralization and the sources of the information and data are mentioned. In the fourth section, the results of the financial decentralization calculated in terms of both macro and province level are discussed. In the conclusion section, the main findings of the study are summarized.

\section{Local Authorities in Turkey}

The government of a country consists of the public authorities and their agencies, which are entities established through political processes that exercise legislative, judicial, and executive authority within a territorial area (IMF, 2014:6). The general government sector consists of all government units and all nonmarket NPIs that are controlled and mainly financed by government units (IMF, 2014:6-10).

The term general government here is used for the total expenditure and revenue size obtained by adding Social Security Institutions and local governments to the central government. General government reflects the structure of public expenditure and revenue in a sense broader than that of central government. Local administrations, and social security institutions are comprised in this definition. General government refers to the expenditure and revenue size when mentioning public sector and expenditure in cross-country comparison (YIlmaz, 2017c).

Within the general government, local administrations, institutions under the central government, social security institutions, extra-budgetary funds and revolving 
funds are included. According to the definition of the Ministry of Development, general government sizes are formulated as follows (Annual Program, 2017):

\section{General Government $=$ Central Government + Local Authorities + Social Security Institutions + Extra budgetary Funds +Revolving Funds}

Turkey is a country with central government structure. Within the context of the restructuring of public administration, one of the areas of structural reform, significant changes have taken place in the legal framework of local governments in Turkey in the first half of the 2000s. The duties and responsibilities of the local governments, which have been postponed for many years and changed daily, have been restructured.

Local government administrations in Turkey can be described as; municipalities, special provincial administrations, municipal affiliated agencies, local government associations, development agencies. In a broad sense, this definition is expanded by Ministry of Finance covering in addition the Development Agencies, Ministry of Youth and Sports Provincial Directories, Agriculture and Rural Development Support Institution and Investment Support and Promotion Agency.

Within this framework, local authority units can be grouped under two main headings including special provincial administrations and municipalities. Special provincial administrations are unit of local authority that are directed by the governor of the central government and represent the central government decision as well as representatives of local authority and operate within the boundaries of the district. Municipalities are local authority whose mayor and decision organs are elected by the voters of the location. In terms of their size, municipalities are divided to metropolitan municipalities, province municipalities, district municipalities. In Metropolitan municipalities, drinking water, sewerage, natural gas and transport services are performed by the separate established administrations which are called affiliated agencies.

Figure 1: Structure of Municipalities in Turkey

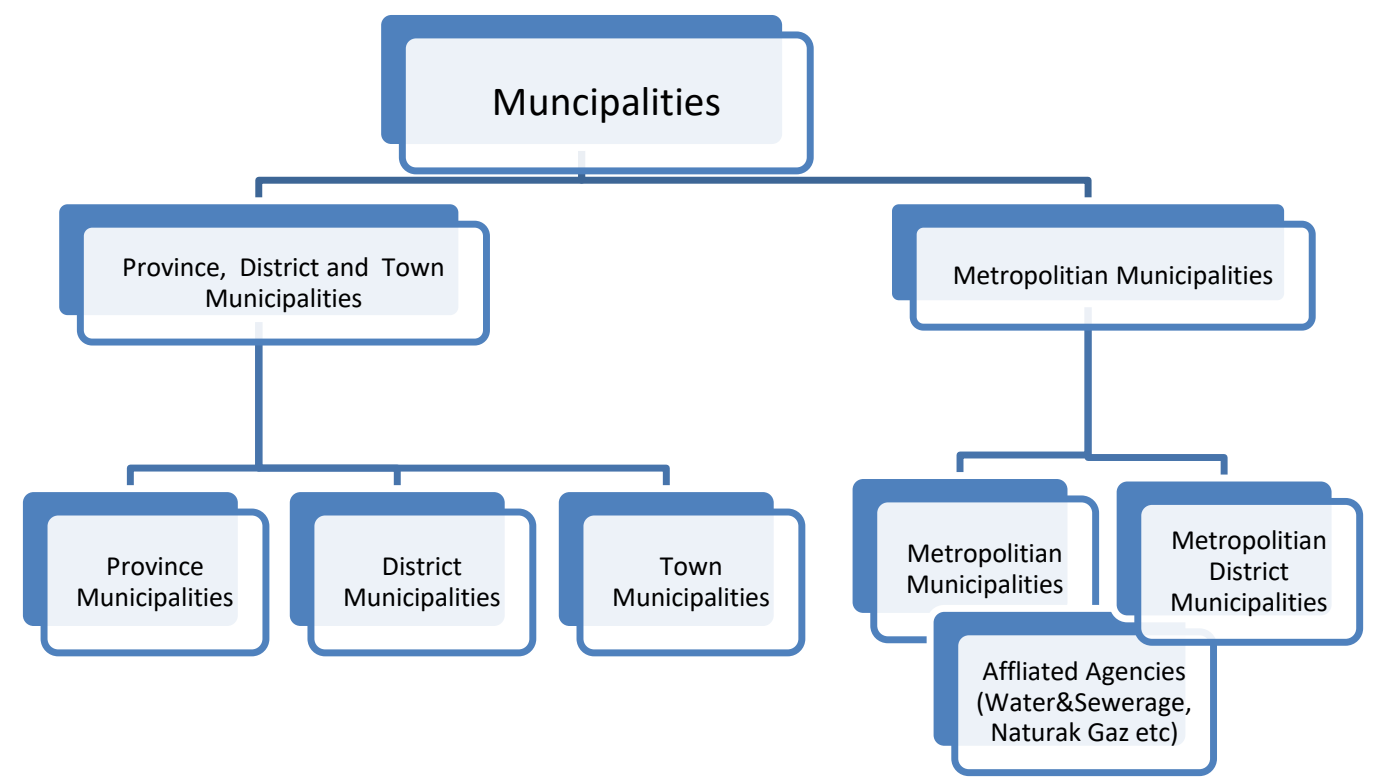


There are 1,397 municipalities in total as of the end of 2016. By the code 6360 enacted in 2014, the number of municipalities was reduced to 1,397 from 2,950 in 2014 and number of metropolitan municipalities increased to 30 from 16. Corresponding to $92 \%$ of the total population live in areas of municipal administration. The ratio of the population living in metropolitan municipalities to the total population is $82.8 \%$, to population living in other municipalities is \%17.2.

\section{Literature Review}

Decentralization is expected to improve delivery of services, even though this may not be stated explicitly through delegation to authority and responsibility for public functions from the central government to subordinate or quasi-independent government including local authorities (Usui, 2007:3; Rondinelli, 1999: 2). Financial responsibility is a main expected component of decentralization for providing better services.

The basic economic arguments in favor of fiscal decentralization rest on the two assumptions: (1) that decentralization will increase economic efficiency as local governments are capable of providing better services due to proximity and informational advantages, and (2) that competition and population mobility across local governments for delivery of public services will ensure the right matching of preferences between local communities and local governments (Tiebout, 1956; Rodríguez-Pose and Krøijer, 2008).

Musgrave (1959) and Oates (1972) have strengthened the theoretical underpinnings of fiscal federalism. The theory of fiscal federalism involves the division of functions and finances of the public sector in a logical way between different units, and in the theory of fiscal federalism, problems arising from the existence of governments at several different levels in the same geographical area are analyzed (Bird, 2005: 146-147; Karagöz, 2014: 13; Yılmaz et al, 2017: 57b) .

The literature of fiscal federalism with neoclassical paradigm perspective includes treatments for the "decentralization theory", which are relatively unrelated. Those are establishment of models for transferring power to lower levels, investigation of intergovernmental transfer systems, Examination of financial mobility and migration in terms of vertical relations, examination of vertical financial imbalance and dependency problem (Bird, 2005: 147, Karagöz, 2014: 14).

Fiscal federalism theories dealing with decentralization focus on maximizing social welfare, which is portrayed as a combination of economic stability, allocative efficiency, and distributive equity. The precise combination and importance attached to each goal depends on the context, but the challenge of decentralization is essentially to locate resources at the level of government that optimizes social welfare (Musgrave 1958: 132-33, 175-178). 
It is important to measure the degree to which each level of government has fiscal impact both revenue and expenditure side and to what degree on service outcomes (Oates 1972: 17; Schneider, 2003; 36).

Expenditures and revenues form the two main fiscal aggregate of financial activity. Central to any system of public finance, they comprise the total amount of money that governments put into or take out of an economy as well as where governments put the money and where they take it from. The current study hypothesizes that the best indicator for the level of fiscal centralization or decentralization is the share of subnational expenditures and revenues (Schneider, 2003; 36).

The ratio of local income and expenditure to the level of public expenditure is not enough to give an idea of fiscal localization. Autonomy at various levels of spending and collection of incomes leads to the differentiation of fiscal decentralization. In terms of expenditure, policy autonomy, budget autonomy, input and result autonomy and monitoring and evaluation structure are important institutional indicators in terms of spending power (Bach et al, 2009; Blöchhliger, 2013).

\section{Figure 2: Pyramid of Fiscal Autonomy}

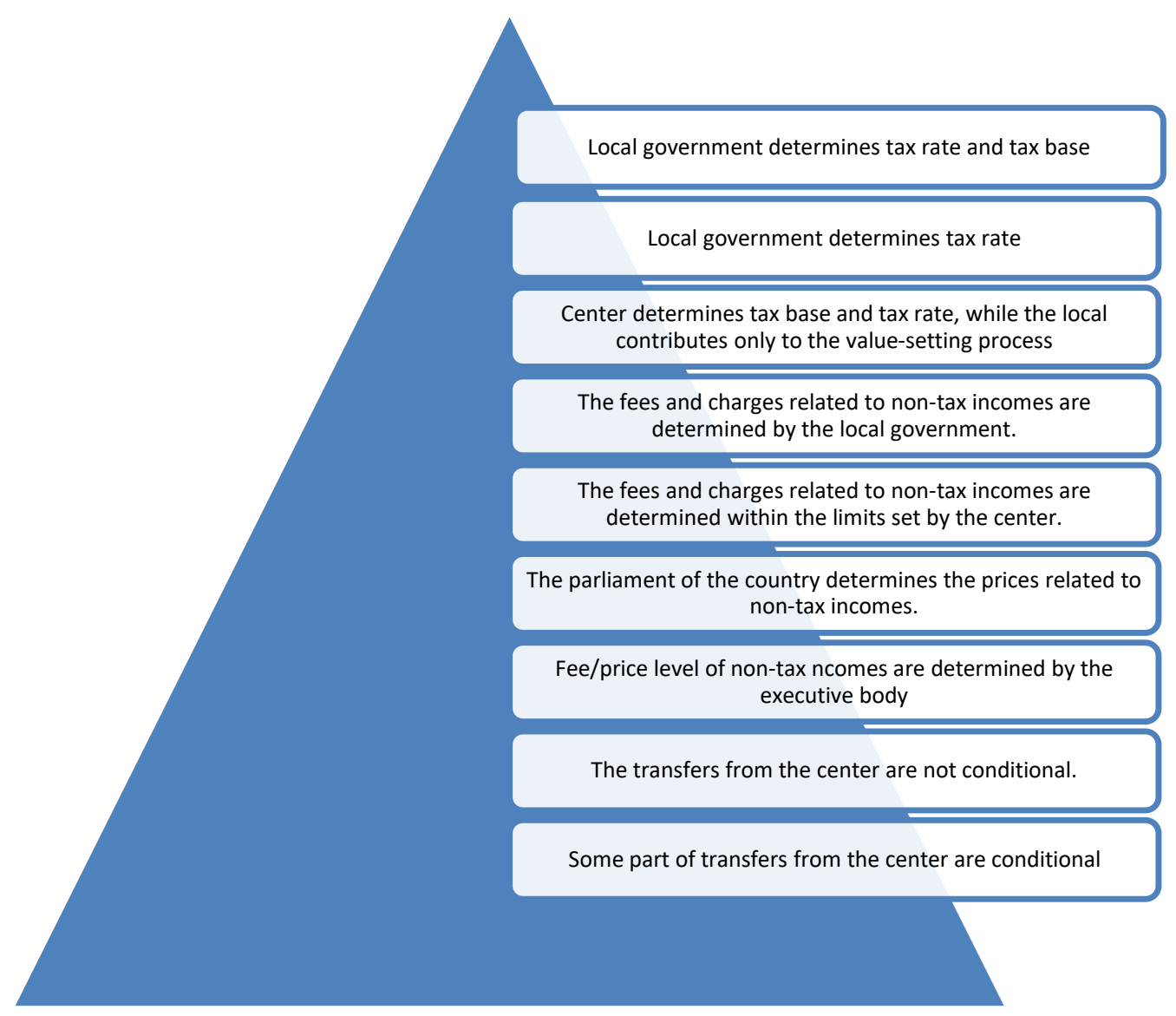


In some researches (Schneider, 2003), they conclude that localization requires a three-dimensional modeling of fiscal, administrative and political aspects. In this way, localization development is clearly measured. In the Figure 2, a pyramid of financial decentralization is given in the framework of spending and income autonomy.

For the intergovernmental income distribution, the distribution of responsibilities and expenditures should be made. Intergovernmental expenditure and income distribution can cause some horizontal and vertical inequalities. Financial transfers have an important role to eliminate the vertical and horizontal inequalities.

Fiscal decentralization has its advantages as well as some disadvantages; (Prudhomme, 1994), (Bird, 1994), (Oates, 1994) the impact of corruption, inadequate knowledge, low quality of local bureaucracy, poor public spending management systems, inability to adapt to technological change and increasing mobility, local interregional spillover effect, economies of scale, harmonization of expenditures, central government's justice responsibility.

\section{Data and Methodology}

It is understood that with fiscal decentralization, local governments use expenditure, income and borrowing facilities more in total public resources. When we look at income perspective, the ratio of local income (LPI) collected in any local unit to public income (TPI) collected in that province or region gives us the fiscal level of decentralization $\left(L D_{R}\right)$ on the basis of country, region or selected government. From the expenditure perspective the ratio of local expenditure (LPE) spended in any local unit to public expenditure (TPE) collected in that province or region gives us the fiscal level of decentralization $\left(L D_{E}\right)$.

$$
\mathrm{LD}_{\mathrm{R}}=(\Sigma \mathrm{LPI}) /(\Sigma \mathrm{TPI}) \text { or } \quad \mathrm{LD}_{\mathrm{E}}=\left(\sum \mathrm{LPE}\right) /\left(\sum \mathrm{TPE}\right)
$$

As it is mentioned previously, the two traditional methods of measuring fiscal decentralization were "expenditure share" and "revenue share". Among these methods, "expenditure share" refers to the ratio of local government spending to total government spending, while "revenue share" refers to the ratio of local government income to total government income (Oates (1972), Akai and Sakata (2002), Woller and Phillips (1998), Zhang and Zou (1998) and Davoodi and Zou (1998).

In this study, various calculations were made about the share of the expenditures and revenues of the local governments belonging to the selected provinces within the total expenditures and total incomes of the institutions under the general administration of the province.

In order to measure the level of fiscal decentralization in a province basis, 8 provinces were selected including İstanbul, Ankara, İzmir, Diyarbakir, Konya, Sivas, 
Çanakkale and Van, first three are the biggest metropolitan cities of Turkey. In the selection of the provinces, population and geographical structure based on the NUTS 1 for the metropolitan cities and the geographical diversity for the other provinces, have been taken into account.

In this study, calculations were made for general fiscal decentralization level in Turkey as well as the share of the local government expenditures and revenues in province total expenditures and revenues in the certain provinces of Turkey. The data of the General Directorate of Public Accounts was used for Turkey in general and for Istanbul, Ankara, Izmir, Diyarbakir, Konya, Sivas, Çanakkale and Van.

The level of fiscal decentralization was taken into account in terms of expenditures and then incomes in selected provinces.

In terms of expenditures, the level of fiscal decentralization is calculated as the ratio of the total expenditure of the local government to the provincial total expenditures. Within the province total expenditures; the expenditure of the central government, the expenditure of the social security institution and the expenditure of the local government are included.

While calculating the central government budget expenditures, the central government budget expenditures under the name of "Centre -undistributed to the provinces" of the General Directorate of Public Accounts were distributed in proportion to the expenditure weights of the provinces and added to the provincial central government budget expenditures for each province.

Local government expenditures are considered together with the first level of economic classification in terms of analytical budget classification.

In terms of expenditures, the level of fiscal decentralization has also been recalculated through the decomposition of inflexible local administration costs. In this calculation, the calculation was made by deducting the personnel expenses and social security expenses which are not included in the flexible expenditure items from the total expenditures of the local administrations. In this second method, the expenditure power of the local governments has been tried to be considered with a more realistic point of view.

In terms of incomes, the level of fiscal decentralization is measured as the ratio of the total incomes of the local governments to provincial total incomes. Within the provincial total incomes; there are central government budget revenues, social security revenues and total revenues of local governments.

In order to prevent the duplication of the $5 \%$ share of the general budget tax revenues collected within the provincial borders of the metropolitan municipalities with the Law on the Granting of Special Provincial Administrations numbered 5779 and 
the General Budget Tax Revenues to the municipalities, it is excluded from central government budget revenues in the calculation made on income basis.

The numbers for social security institution revenues are calculated by multiplying the average premium collection income across Turkey by the number of active insured persons subject to calculation.

It was understood that the Ankara provincial central government budget expenditure total is above the amounts actually realized due to the difference caused by being a capital city and therefore the calculation was made by subtracting current transfers, capital transfers and lending items from this total.

The central government budget revenue-expenditure amounts and local administration income-expenditure amounts at the provincial level are obtained from the data set announced by the General Directorate of Public Accounts. The calculations are made over the 2006-2013 period.

In the context of the above explanations, the following table summarizes the calculations made on the general government expenditures in selected provinces.

Table 1: Summary Province Base Calculation Table

\begin{tabular}{|c|c|}
\hline $\begin{array}{l}\text { Province Level } \\
\text { Total General Government Expenditure }\end{array}$ & $\begin{array}{c}\text { Province Level } \\
\text { Total General Government Revenue }\end{array}$ \\
\hline $\begin{array}{l}\text { - Provincial central government budget } \\
\text { central administration expenditures by } \\
\text { provinces, central expenditures } \\
\text { (undistributed amount) were } \\
\text { distributed to the provinces. } \\
\text { Current transfers in Ankara, capital } \\
\text { transfers and lending minus } \\
\text { repayment items were not taken into } \\
\text { account. } \\
\text { - Provincial social security expenditures: } \\
\text { provincial health expenditures + } \\
\text { provincial insurance expenditures } \\
\text { - Provincial local administration } \\
\text { expenditures. }\end{array}$ & $\begin{array}{l}\text { Provincial central government budget } \\
\text { revenues: With the Law No. } 5779 \text { on } \\
\text { the metropolitan municipalities, the } \\
5 \% \text { share allocated from the total } \\
\text { budget revenues collected within the } \\
\text { provincial borders was subtracted } \\
\text { from the central government budget } \\
\text { revenues. }\end{array}$ \\
\hline
\end{tabular}




\section{Findings}

\subsection{Fiscal Decentralization in General Government}

General government expenditures and revenues showed a significant increase especially in the post-crisis period in Turkey. When we look at primary expenditures, this increase is noticeable. Primary expenditures, which were $24 \%$ of GDP at the beginning of the 2000 s, rose rapidly to $35 \%$ especially in the post-crisis period. Revenues, on the other hand, were accompanied by an increase in social funds (social security premium incomes) other than tax revenues. The increase in the tax collection was limited.

On the other hand, this development in tax revenues is thought to potentially negatively affect local governments. If tax incomes had been incurred in place of social funds, the level of financial localization would be higher in Turkey due to the income sharing system.

Figure 3: General Government Revenue and Expenditures As A Share of GDP

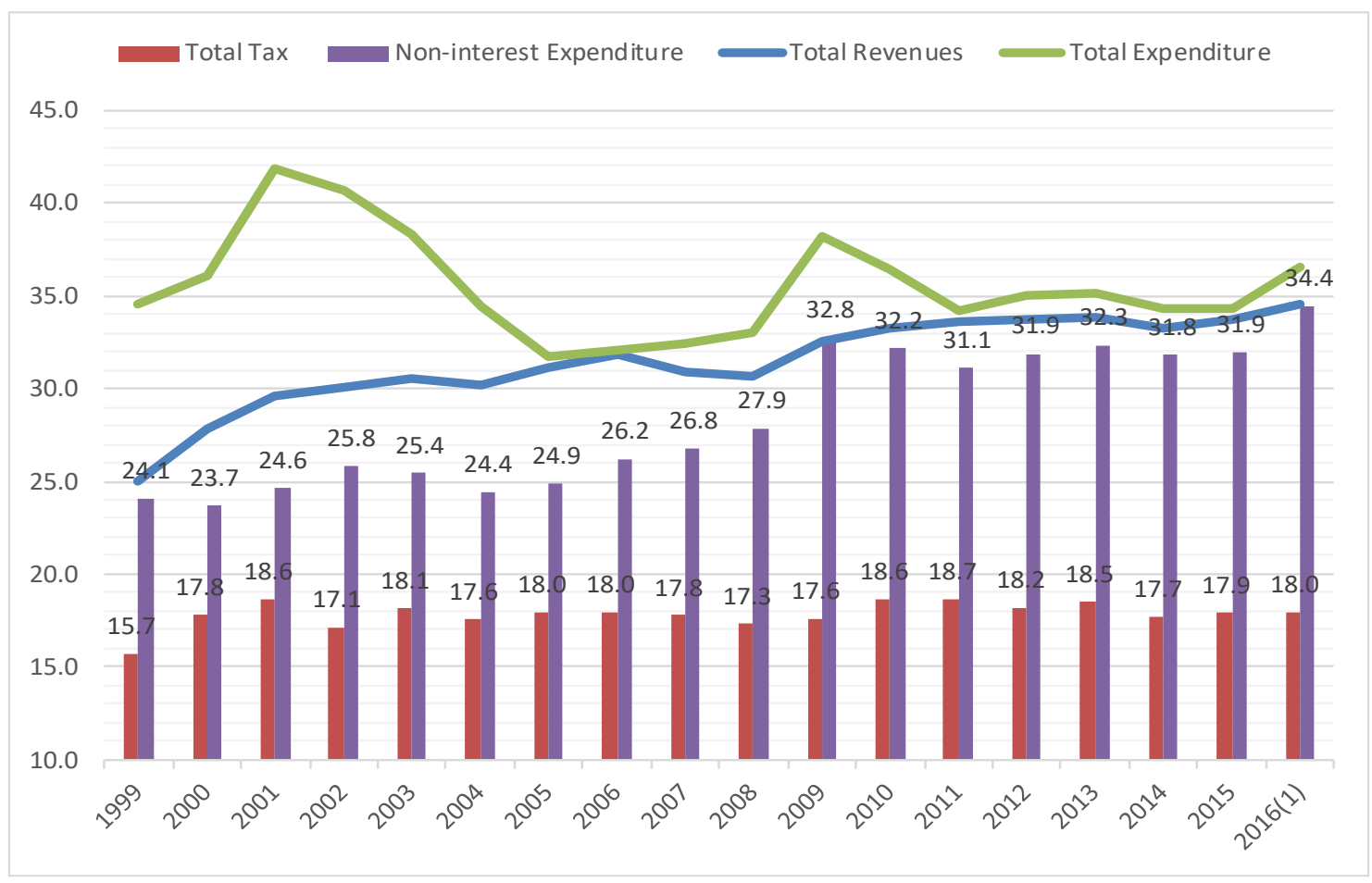

The level of fiscal decentralization in Turkey is increasing with the changing legal framework, especially since the year 2000. As a percentage of GDP at the point reached today, local governments' spending amounts reached $5 \%$ of GDP, and up to $12 \%$ in total public expenditures. 
In the 2000-2016 period, GG primary expenditures, as \% of GDP, increased by 45.4\%. The biggest contribution came from transfer expenditures (primary) with $57.1 \%$, followed by current expenditures with $42 \%$. The contribution of capital expenditures was relatively small with 1\% (Yılmaz 2017c).

Table 2: General Government Expenditures (of GDP, \%) and Contributions to NIE (\%)

\begin{tabular}{|c|c|c|c|c|c|c|c|}
\hline & \multicolumn{3}{|c|}{ as a share of GDP } & \multicolumn{3}{|c|}{$\%$ Change } & \multirow{2}{*}{$\begin{array}{c}\% \\
\text { Contr. } \\
16 / 00 \\
\end{array}$} \\
\hline & 2000 & 2007 & $2016(1)$ & $07 / 00$ & $16 / 07$ & $16 / 00$ & \\
\hline Total Expenditures & 36.1 & 41.8 & 36.5 & 15.9 & -12.6 & 1.2 & \\
\hline Non-interest Expenditures & 23.7 & 26.8 & 34.4 & 13.0 & 28.6 & 45.4 & 100.0 \\
\hline Transfer Exp. Exc. Interest Pay. & 8.2 & 20.0 & 14.3 & 143.9 & -28.3 & 74.9 & 57.1 \\
\hline Current Exp. & 12.2 & 12.8 & 16.7 & 5.1 & 30.5 & 37.1 & 42.0 \\
\hline Capital Exp. & 3.3 & 3.5 & 3.4 & 3.6 & -0.5 & 3.1 & 1.0 \\
\hline Transfer Exp. & 20.6 & 25.6 & 16.4 & 24.2 & -35.8 & -20.3 & -38.9 \\
\hline Interest Payments & 12.4 & 5.6 & 2.1 & -54.7 & -62.6 & -83.1 & \\
\hline
\end{tabular}

Notes: (1) Estimated. (2) Contributions to real change in General Government Non-Interest Expenditures to GD। Source: Yılmaz, 2017c

When we look at the institutional distribution of general government primary expenditures, it is seen that the greatest increase in 2000's was due to social security institutions and budget. Local governments are third in the real increase.

Table3: General Government Non-interest Expenditure Development by Institutions

\begin{tabular}{|c|c|c|c|c|c|}
\hline & \multicolumn{2}{|c|}{ GDP (\%) } & \multirow{2}{*}{$\begin{array}{c}\text { Change (\%) } \\
(2015-19) / \\
(2000-04) \\
\end{array}$} & \multicolumn{2}{|c|}{ \% Distribution } \\
\hline & $\begin{array}{c}2000- \\
2004\end{array}$ & $\begin{array}{c}2015- \\
2019\end{array}$ & & $\begin{array}{c}2000- \\
2004\end{array}$ & $\begin{array}{c}2015- \\
2019\end{array}$ \\
\hline Non-interest Expenditures & 24.8 & 33.7 & 35.9 & 100.0 & 100.0 \\
\hline Central Government & 12.1 & 17.0 & 40.8 & 48.6 & 50.4 \\
\hline Social Sec.Institutions & 7.3 & 10.4 & 42.1 & 29.4 & 30.7 \\
\hline Local Government & 3.0 & 3.9 & 29.4 & 12.2 & 11.6 \\
\hline Revolcing Funds & 1.5 & 1.8 & 23.4 & 5.9 & 5.3 \\
\hline Extra budgetary Funds & 1.0 & 0.7 & -33.1 & 3.9 & 1.9 \\
\hline
\end{tabular}

Source: Yılmaz, 2017b

It is understood that with fiscal decentralization, local governments use spending, income and borrowing facilities more in total public resources. When we 
look at the income side, the result of dividing the total public revenues by the local revenues gives us the level of macroeconomic level of fiscal decentralization $\left(L D_{R}\right)$.

The revenue and expenditures of local governments in Turkey have increased as a proportion of GDP, while the level of fiscal decentralization has shown a distinctive structure especially since 2000s. Today, the rates of financial decentralization in the last 10 years range from $11-14 \%$. While the spending ratio was higher than the income ratio in the period of 2006-2008, those ratios showed a changing structure in which the income ratio was higher than the spending ratio in 2009-2012 period, which was also encountered in the global crisis. Although the same structure will continue to differentiate in 2013-2015 period, it is seen that spending again in 2016, especially due to the impact of the metropolitan municipalities. The decline in income and expenditure localization rates over the last four years is largely due to relatively lower income and spending in local authorities.

Figure 4: Macro Fiscal Decentralization Level in Turkey (2006-2016)

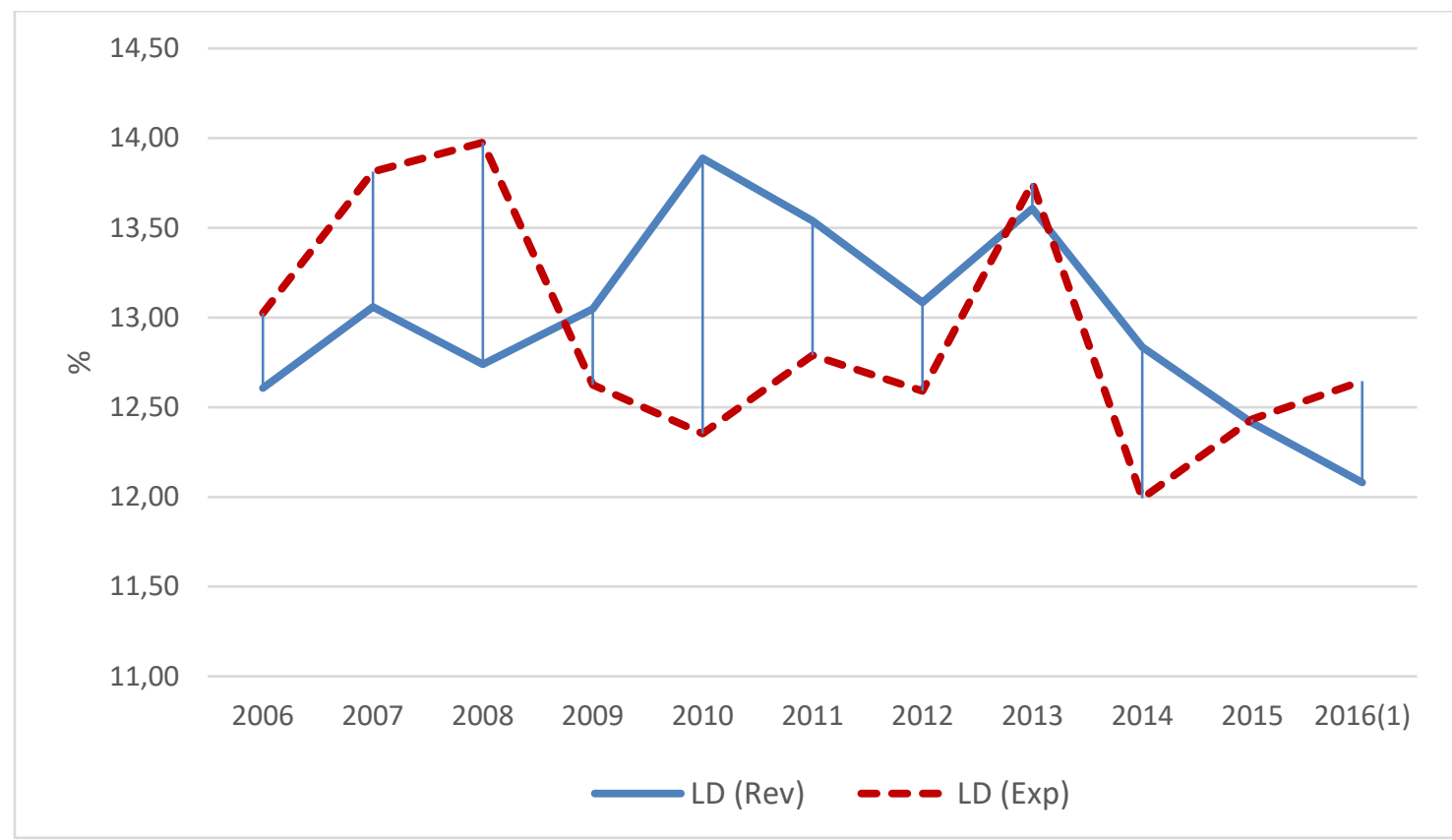

Local spending, which is important in terms of public spending and level of fiscal decentralization in macro-level in Turkey, has increased in real terms, but still the GDP ratio of spending by local governments is well below the average of European Union countries as seen in the following figure. In fact, as a result of the policy discourses that began in the 2000s, the expected rate of fiscal localization was higher. But the real policy implementation of the ruling governments has not been achieved at the desired level. 
Güzel, A. \& H. H. Yılmaz (2018), “Fiscal Decentralization in Turkey and Differentiation in Selected Provinces", International Journal of Public Finance, Vol.3, No.1, pp. 63-82.

Figure 5: Local Government Expenditures Comparing EU Countries (Share of GDP, 2016)

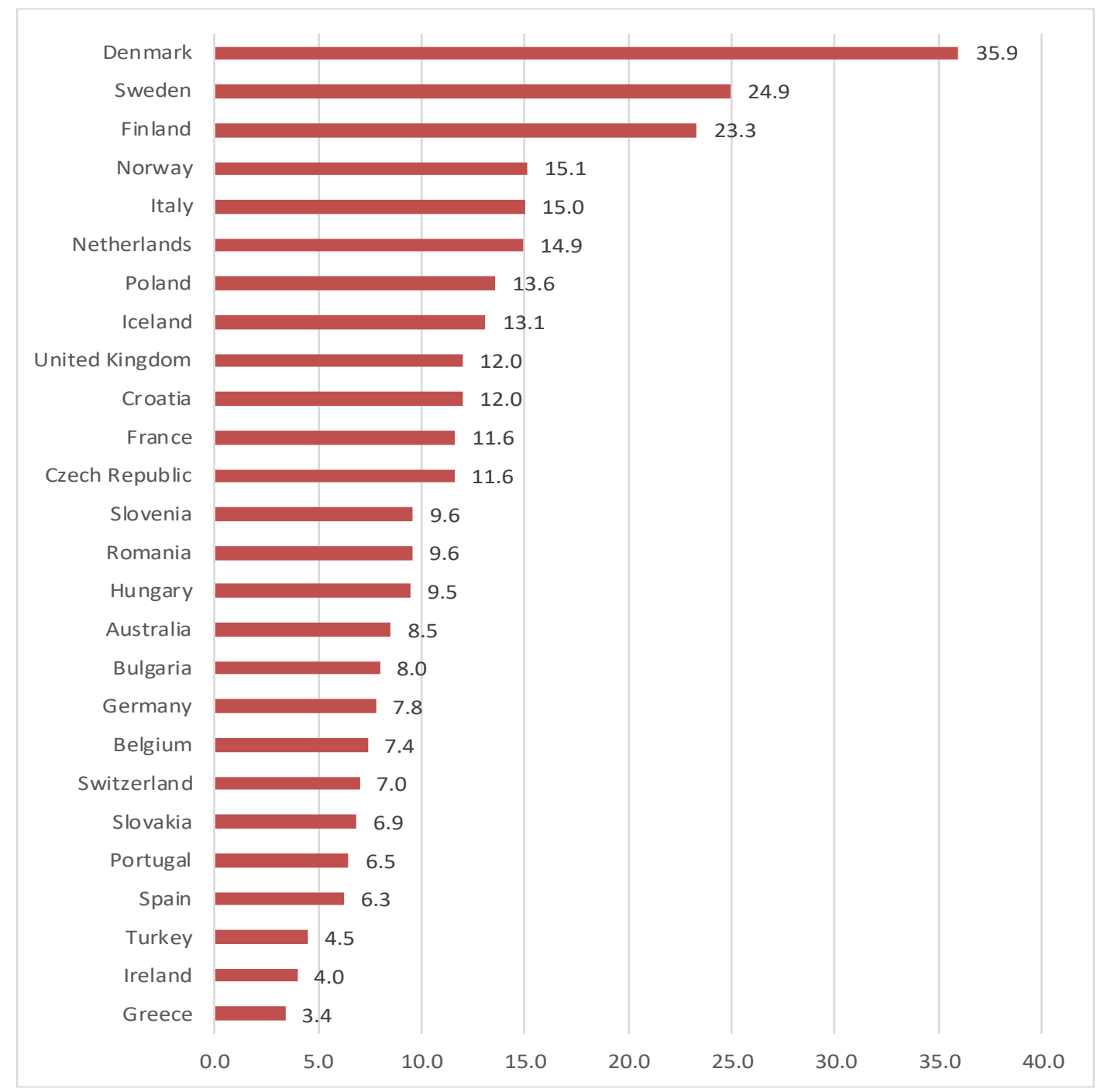

Source: Eurostat (Access Date: 30 June, 2017)

\subsection{Fiscal Decentralization in Selected Provinces}

In terms of incomes, there are quite different results between the provinces in the level of fiscal decentralization and in the per capita local government revenues. The highest level of fiscal decentralization occurred in Van, Diyarbakır and Sivas provinces at $27 \%, 25 \%$ and $24 \%$ respectively. The per capita local government revenues in the same provinces were realized as $0.64,0.67$ and 0.93 thousand TL, respectively, and these figures are considerably lower compared to those of Istanbul, Ankara and izmir.

In these cases, it is seen that the high level of fiscal decentralization is not caused by the demand of local goods and services, the economic activities are 
underdeveloped and the central government revenues are low and therefore the fiscal decentralization level is relatively high.

The fact that the per capita income of local governments in Diyarbakır, Sivas, Konya, Çanakkale and Van are relatively low presents that local governments are more dependent on the center in terms of financial capacity and therefore have limitations in terms of expenditure power from the criteria of financial autonomy.

In terms of metropolitan provinces, it is calculated that the level of fiscal decentralization is relatively lower level, $8 \%$ in Istanbul, 10\% in Ankara and 9\% in Izmir.

Looking at the per capita central government revenues, Istanbul ranks first with 16,25, Ankara second with 13.55, and İzmir third with 11.34. These results indicate that in these three large-scale cities, economic activities have developed. The per capita local government revenues in these provinces are at levels of 1.54, 1.76 and 1.35 , respectively, and above the levels in other underdeveloped provinces. This situation shows that the policies of vertical and horizontal equalization are inadequate in solving the inequalities of resource sharing policies arising between developed and ill-developed provinces. At the same time, regional development disparities and the inadequacy of equalization and resource transfer policies has appeared. It is estimated that there are significant differences in the levels of fiscal decentralization between provinces within the framework of policies implemented by the government.

In the less-developed provinces like Van, Diyarbakir and Sivas, the per capita central government revenues as well as the per capita local government revenues remained relatively low. In these provinces high fiscal decentralization rate has not occurred due to demand of local goods and services, the real cause of that was the underdevelopment of the economic activity and therefore low central government revenues and therefore it seems to be relatively high fiscal decentralization rate. Moreover, in terms of revenues, the rate of fiscal decentralization is also seen as not a sufficient criterion by itself.

Table 4: Fiscal Decentralization Level (Revenue, 2013)

\begin{tabular}{lrrrrr}
\hline \multicolumn{1}{c}{ (000 TL) } & $\begin{array}{c}\text { Central } \\
\text { Government } \\
\text { Revenue }\end{array}$ & $\begin{array}{c}\text { Local } \\
\text { Government } \\
\text { Revenue }\end{array}$ & $\begin{array}{c}\text { Fiscal } \\
\text { Decentralization } \\
\text { Level }\end{array}$ & $\begin{array}{c}\text { Per Capita } \\
\text { Central Govern. } \\
\text { Revenue }\end{array}$ & $\begin{array}{c}\text { Per Capita } \\
\text { Local Govern. } \\
\text { Revenue }\end{array}$ \\
\hline İstanbul & $230,071,083$ & $21,827,130$ & $\mathbf{0 . 0 8}$ & 16.25 & 1.54 \\
Ankara & $68,366,010$ & $8,887,781$ & $\mathbf{0 . 1 0}$ & 13.55 & 1.76 \\
İzmir & $46,055,332$ & $5,501,643$ & $\mathbf{0 . 0 9}$ & 11.34 & 1.35 \\
Diyarbakır & $1,956,634$ & $1,076,165$ & $\mathbf{0 . 2 5}$ & 1.22 & 0.67 \\
Konya & $4,125,518$ & $2,010,068$ & $\mathbf{0 . 2 2}$ & 1.98 & 0.97 \\
Sivas & $1,060,677$ & 583,170 & $\mathbf{0 . 2 4}$ & 1.7 & 0.93 \\
Çanakkale & $1,116,956$ & 456,355 & $\mathbf{0 . 1 9}$ & 2.22 & 0.91 \\
Van & $1,093,305$ & 686,421 & $\mathbf{0 . 2 7}$ & 1.02 & 0.64 \\
\hline
\end{tabular}

Source: Based on the MoF data our own calculation 
When we look at financial decentralization in terms of expenditure, the picture changes according to the income results.

In the metropolitan areas like Ankara, Istanbul and İzmir, the responsibility of local administrations is high and central government responsibility is relatively low in terms of distribution of duty / expenditure.

Diyarbakır, Sivas, Van and Çanakkale, the central administration is emphasized in terms of distribution of duties and expenditures, and the expenditures of local administrations per capita are low. This suggests that the applied horizontal equalization policies are inadequate.

Table 5: Fiscal Decentralization Level (Expenditure, 2013)

\begin{tabular}{lrrrcc}
\hline \multicolumn{1}{c}{ (000 TL) } & $\begin{array}{c}\text { Central } \\
\text { Government } \\
\text { Expenditure }\end{array}$ & $\begin{array}{c}\text { Local } \\
\text { Government } \\
\text { Expenditure }\end{array}$ & $\begin{array}{c}\text { Fiscal } \\
\text { Decentralization } \\
\text { Level }\end{array}$ & $\begin{array}{c}\text { Per Capita } \\
\text { Central Govern. } \\
\text { Expenditure }\end{array}$ & $\begin{array}{c}\text { Per Capita } \\
\text { Local Govern. } \\
\text { Expenditure }\end{array}$ \\
\hline İstanbul & $93,939,268$ & $21,780,242$ & $\mathbf{0 . 2 3}$ & 2.79 & 1.54 \\
Ankara & $85,020,720$ & $10,008,089$ & $\mathbf{0 . 1 2}$ & 12.31 & 1.98 \\
İzmir & $36,937,860$ & $5,720,945$ & $\mathbf{0 . 1 5}$ & 4.75 & 1.41 \\
Diyarbakır & $13,173,532$ & $1,132,592$ & $\mathbf{0 . 0 9}$ & 6.25 & 0.7 \\
Konya & $17,289,788$ & $2,572,864$ & $\mathbf{0 . 1 5}$ & 4.99 & 1.24 \\
Sivas & $6,494,747$ & 644,355 & $\mathbf{0 . 1 0}$ & 6.93 & 1.03 \\
Çanakkale & $4,759,652$ & 524,678 & $\mathbf{0 . 1 1}$ & 5.47 & 1.04 \\
Van & $8,834,401$ & 821,033 & $\mathbf{0 . 0 9}$ & 6.41 & 0.77 \\
\hline
\end{tabular}

Source: Based on the MoF data our own calculation

When the level of fiscal decentralization in terms of expenditures is considered, the highest level is in Istanbul with $23 \%$, İmir and Konya share the second place with $15 \%$ and Ankara third place with $12 \%$.

When the central government budget expenditures are considered in the selected provinces, İstanbul is in the first level with expenditures of about 94 billion TL. Per capita central administration expenditure is also highest in Ankara with 12.31 thousand TL. The provincial government expenditures are in the second rank after Istanbul with approximately 10 billion TL. In Ankara, the per capita local government expenditures are at the first rank with 1.98. Since the central government budget expenditures are very high in Ankara, the level of fiscal decentralization remains at $12 \%$.

Istanbul is in the first place in terms of per capita local administration expenditures as well as level of fiscal decentralization and second place behind Ankara 
in terms of per capita local government expenses due to population density. Although the level of fiscal decentralization in Ankara is relatively low, per-capita local government expenses ranks first.

It is seen that the metropolitan areas such as Ankara, Istanbul and Izmir have a greater responsibility for local governments in terms of distribution of duty / expenditure and the duties and responsibilities of central government are relatively low especially in Istanbul. This is because the lowest level among the selected provinces belongs to Istanbul when the central administration expenditures per capita are examined. In Istanbul, the central administration expenditure per capita is 2.790 TL. On the other hand, it is 6.250 TL in Diyarbakir, 6.410 TL in Van and 6.930 TL in Sivas.

The reason why Istanbul has a high level of fiscal decentralization is that the demand for local goods and services is high because the population is considerably higher than the others. This suggests that there is a direct relationship between the population and local demand for goods and services. Moreover, the high level of fiscal decentralisation in Istanbul is consistent with the "fiscal decentralization" theorem by Oates.

The lowest rates are $9 \%$ in Van and Diyarbakır in terms of fiscal decentralization levels. In Sivas and Çanakkale, the levels of financial decentralization are $10 \%$ and $11 \%$ respectively.

In Diyarbakır, Sivas, Van and Çanakkale, the central government is emphasized in terms of distribution of duties and expenditures, and the expenditures of local governments per capita are low. This suggests that the applied horizontal equalization policies are inadequate. Taking into account the migration from these cities to big cities, this result is in line with the "Tiebout Model".

As a result, the following graph shows us that fiscal decentralization based on income in economically developed areas (Ankara, İstanbul and İzmir) is significantly higher than fiscal decentralization level based on expenditure. On the contrary, in the economically less developed ones, it is seen that fiscal decentralization level based on expenditure is higher and the difference is much bigger between fiscal decentralization levels. This shows us that the horizontal disparity is partly solved by the existing resource distribution system, but the structural problem continues. This is because own source revenues in the selected provinces is far from meeting the need for spending, and the amount of tax revenues in the provinces that are subject to distribution for the metropolitan cities is low. 
Figure 6: Fiscal Decentralization in Selected Provinces (2013)

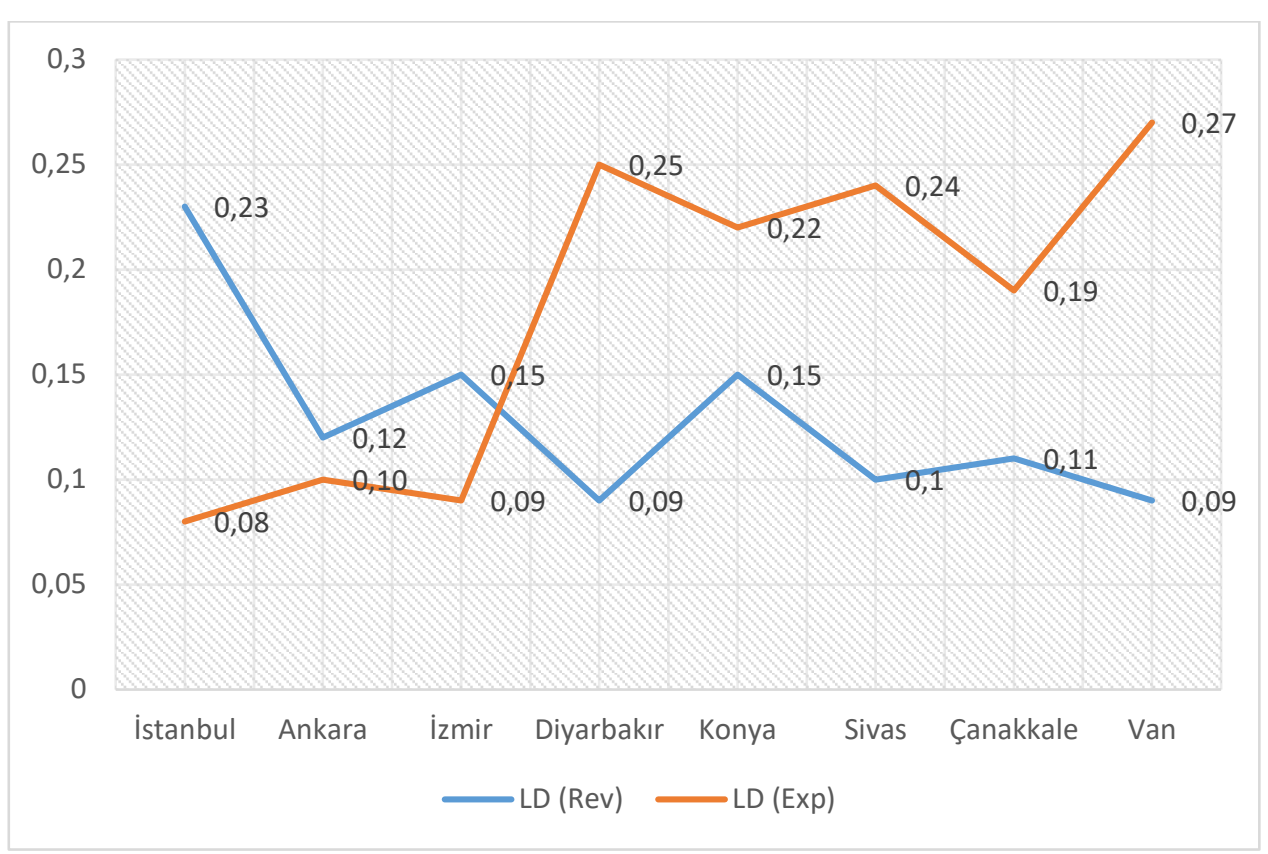

When we look at the expenditure-oriented financial decentralization level during the period of 2010-13, we find that the level of fiscal decentralization were increased as a general trend throughout the period.

When the level of fiscal decentralization in terms of expenditures is considered in 2010, the highest level is in Istanbul with $21 \%$, Izmir is the second with $13 \%$ and Ankara third place with $12 \%$. In 2011 similarly, İstanbul is the first with $21 \%$, İzmir is the second with $15 \%$ but, Konya is the third with $12 \%$. In 2012, likewise, İstanbul is the first with $21 \%$, Izmir is the second with $15 \%$ and Konya is the third with $13 \%$.

Table 6: Fiscal Decentralization Level (Expenditure, 2010-2013)

\begin{tabular}{|l|l|l|l|l|}
\hline & $\mathbf{2 0 1 0}$ & $\mathbf{2 0 1 1}$ & $\mathbf{2 0 1 2}$ & $\mathbf{2 0 1 3}$ \\
\hline İstanbul & 0.21 & 0.21 & 0.21 & 0.23 \\
\hline Ankara & 0.12 & 0.09 & 0.09 & 0.12 \\
\hline İzmir & 0.13 & 0.15 & 0.15 & 0.15 \\
\hline Diyarbakır & 0.07 & 0.07 & 0.09 & 0.09 \\
\hline Konya & 0.10 & 0.12 & 0.13 & 0.15 \\
\hline Sivas & 0.08 & 0.09 & 0.10 & 0.10 \\
\hline Çanakkale & 0.09 & 0.10 & 0.10 & 0.11 \\
\hline Van & 0.07 & 0.06 & 0.08 & 0.09 \\
\hline
\end{tabular}

Source: Based on the MoF data our own calculation 
Fiscal decentralization level in terms of revenue, in 2010, it is shown that, Van, Diyarbakır and Sivas are the first three provinces that have the highest rank. This result is similar with the ranks of 2011 and 2012. When we look at the metropolitan cities, the level of fiscal decentralization is relatively low, 9\% in Istanbul, $9 \%$ in Ankara and $10 \%$ in Izmir in 2010.

The limited extent of income generating capacity due to the difference in economic development level differentiates income-oriented fiscal decentralization as we mentioned earlier. This differentiation actually leads to some sort of fiscal illusion, and financial localization seems to be high in less developed regions such as Van, Diyarbakır and Sivas.

Table 6: Fiscal Decentralization Level (Revenue, 2010-2013)

\begin{tabular}{|l|c|c|c|c|}
\hline & $\mathbf{2 0 1 0}$ & $\mathbf{2 0 1 1}$ & $\mathbf{2 0 1 2}$ & $\mathbf{2 0 1 3}$ \\
\hline İstanbul & 0.09 & 0.09 & 0.07 & 0.08 \\
\hline Ankara & 0.09 & 0.10 & 0.10 & 0.10 \\
\hline İzmir & 0.10 & 0.10 & 0.09 & 0.09 \\
\hline Diyarbakır & 0.30 & 0.28 & 0.27 & 0.25 \\
\hline Konya & 0.23 & 0.23 & 0.24 & 0.22 \\
\hline Sivas & 0.28 & 0.26 & 0.24 & 0.24 \\
\hline Çanakkale & 0.21 & 0.19 & 0.18 & 0.19 \\
\hline Van & 0.37 & 0.32 & 0.35 & 0.27 \\
\hline
\end{tabular}

Source: Based on the MoF data our own calculation

\section{Conclusion}

Fiscal decentralization in Turkey has been addressed in terms of the size of local governments and revenues. The original contribution of the work comes from the cases of selected provinces. In selected cases, the public sector was viewed as a whole and an analysis of two-way fiscal decentralization, including expenditure and income, was made.

In Turkey, income transfers from central government to local governments are essentially unconditional transfers. In this regard, the application of transfer is a matter of financial autonomy of local governments. The main purpose of transfers is to provide vertical equalization between governments. Results indicate that there is no clear-cut calculation methodology for achieving vertical equality.

The objective for achieving horizontal equalization in the transfer system remains also limited, since there is not enough differentiation for municipalities with different levels of regional development and local service needs. As a result, it is considered necessary for the distribution criterion to provide horizontal equality by adding the parameters including the difference in needs of the service, the level of 
regional development, tax collection amount, central authorities' expenditures, population and demography of population by age groups.

Fiscal decentralization rates differ between provinces. Intergovernmental revenue sharing system and differentiation in own source revenues mainly resulting from the income levels of the regions clearly shows that there has been an inadequate vertical and horizontal imbalances and current sharing system somehow increases inequalities among provinces.

Regarding decentralization theory of Oates, principles such as prioritization of local expenditures by local sources of income and transfers to be made from the center for internalization of externalities, regional inequalities and catching of scale economy in aggregate cannot find enough application in Turkey.

\section{References}

Akai, N. and M. Sakata (2002), "Fiscal Decentralization Contributes to Economic Growth: Evidence from State-level Cross-section Data for the United States", Journal of Urban Economics, 52(1), pp. 93-108.

Bağlı, Mehmet Selim, "Mali Yerelleşme Düzeyinin Ölçümü (Mali Özerklik Derecesi)", TODAiE Çağdaş Yerel Yönetimler, Çağdaş Yerel Yönetimler, Cilt 23 Sayı 2 Nisan 2014, s. 27-47.

Bird, R. (1994). Decentralizing infrastructure: For good or for ill? (Vol. 1258). World Bank Publications.

Bird, M.R., (2005), Fiscal Federalism, The Encyclopedia of Taxation And Tax Policy (ed. Cordes J.J., Ebel R.D., Gravelle J.G.), Washington: The Urban Institute Press

Burki, Javed Shahid-Perry, Guillermo-Dillinger, William, Beyond The Center: Decentralizing The State, Prepublication Conference Edition THE WORLD BANK WASHINGTON, D.C, http://siteresources.worldbank.org/PAKISTANEXTN/ Resources/pdf-Files-in-Events/IRISD /beyondTheCenter.pdf(07.10.2010), 1999

Bach, S., Blöchliger, H., \& Wallau, D. (2009). The spending power of sub-central governments: a pilot study. Organisation for Economic Co-operation and Development.http://www.oecd.org/ctp/federalism/42783063.pdf

Bahl, Roy (1999), Implementation Rules For Fiscal Decentralisation, International Studies Program, School of Policy Studies, Georgia State University, Atlanta, Georgia

Boadway, R. W., Roberts, S., \& Shah, A. (1994). The reform of fiscal systems in developing and emerging market economies: a federalism perspective (Vol. 1259). World Bank Publications. 
Blöchhliger, H. and D. King (2006), "Fiscal Autonomy of Sub-Central Governments", OECD Working Papers on Fiscal Federalism, No. 2, OECD Publishing.http://dx.doi.org/10.1787/5k97b127pc0t-enhttp://asset.keepeekcache.com/medias/domain21/_pdf/media1166/187020n20pti6y47/large/16.jpg

Blöchhliger Hansjörg (2013), Measuring Decentralization: The OECD Fiscal Decentralization Database, Measuring Fiscal Decentralisation, Concepts and Policies, ed. By Junguh Kim, Jorgen Lotz and Hansjorg Blöchhliger, OECD

Davoodi, H. and H. Zou (1998), "Fiscal Decentralization and Economic Growth - A Cross-Country Study", Journal of Urban Economics 43, 244-57.

EUROSTAT, Government Finance Statistics Database (Access date: 30 June 2017)

Güzel, Ahmet (2014) Türkiye'de Mali Yerelleşme ve Seçilmiş Iller Bazında Incelenmesi,Ankara Üniversitesi Sosyal Bilimler Enstitüsü Maliye Anabilim Dalı YL Tezi

IMF, 2014 Government Finance Statistics Manual

Karagöz, Berkan, Mali Yerelleşme ve Yatay Eşitsizlik Sorunu: Türkiye Örneği, Doktora Tezi, AÜ Sosyal Bilimler Enstitüsü, 2014

Kalkınma Bakanlığı Ekonomik ve Sosual Göstergeler, http://www.kalkinma.gov.tr/ Pages/EkonomikSosyalGostergeler.aspx, (Erişim tarihi 2 Ekim 2015)

Litvack, J. and Jessica Seddon, "Decentralization Briefing Notes", Washington, DC: World Bank, 1999

Litvack, Jennie, Seddon, Jessica, "Decentralization Briefing Notes", World Bank Institute, WBI Working Papers, http://info.worldbank.org/etools/docs/ library/8680/Decentralization\%20Briefing\%20 Notes.pdf (07.10.2010), 2004

Maliye Bakanlığı Muhasebat Genel Müdürlüğü Belediye Verileri, https://www.muhasebat. gov.tr, (Erişim tarihi 2 Ekim 2015)

Musgrave, R., (1959), The Theory of Public Finance, McGraw-Hill, New York

Ministry of Development, 2017 Annual Program

Oates, W.E. (1972) Fiscal Federalism. New York: Harcourt Brace Jovanovich.

Oates, W.E. (1999) An Essay on Fiscal Federalism, Journal of Economic Literature, Vol. 37, No. 3 (Sep., 1999), pp. 1120-1149

Prud'Homme, R. (1994). On the dangers of decentralization (Vol. 1252). World Bank Publications.

Rodríguez-Pose, Andrés and Anne Krøijer (2008), Fiscal decentralization and economic growth in Central and Eastern Europe, London School of Economics

Rondinelli Dennis (1999), "What and Why", Decentralization Briefing Notes içinde, Litvack, J. and Jessica Seddon, Washington, DC: World Bank 
Schneider, Aaron, (2003), "Decentralization: Conceptualization and Measurement", Studies in Comparative International Development, Fall 2003, Vol. 38, No. 3, pp. 32-56.

Tanzi, V. (1995) Fiscal federalism and decentralization: a review of some efficiency and macroeconomic aspects. In M. Bruno and B. Pleskovic (eds), Annual World Bank Conference on Development Economics 1995. Washington, DC: World Bank.

Ussi, Norio (2007), Critical Issues of Fiscal Decentralization, ERD Technical Note No. 21, Asian Development Bank

Woller, G.M. and K. Phillips (1998), "Fiscal Decentralization and IDC Economic Growth: An Empirical Investigation", Journal of Development Studies, 34(4), pp. 139148.

Yılmaz, H. Hakan (a), "Financial Structure of the Municipalities and Differentiation in Financial Structure", UMT Publication, Ankara 2013

Yılmaz, H. Hakan, F. Emil, B. Kerimoğlu (b), "Yerel Yönetimler Maliyesi: Temel ilkeler ile Mevzuat ve Uygulama Açısından Türk Yerel Yönetim Yapılanmasında Mali Yönetim ve Kaynak Kullanım Sistemi”, PYB Yayını, 2017

Yılmaz, H. Hakan (c), "Government, Redistribution and Social Protection in Turkey", UNDP, 2017 (coming soon).

Zhang, T. and H.-f. Zou (1998), "Fiscal Decentralization, Public Spending, and Economic Growth in China", Journal of Public Economics, 67(2), pp. 221-240. 